\title{
Microbial Properties of Ethiopian Marketed Milk and Milk Products and Associated Critical Points of Contamination: An Epidemiological Perspective
}

\author{
Zelalem Yilma \\ East Africa Dairy Development (EADD) Program, Addis Ababa \\ Ethiopia
}

\section{Introduction}

In Ethiopia, milk production systems can be categorized into urban, peri-urban and rural, based on location (Reda, 2001). Located around Addis Ababa and regional towns, urban and peri-urban systems are market oriented and make use of the high demand in urban areas. The rural system is part of the subsistence farming system and includes pastoralists, agropastoralists, and mixed crop-livestock producers mainly in the highlands. As this system is not market oriented, most of the milk produced is retained for home consumption. The surplus is mainly processed using traditional technologies into more shelf stable products such as Ergo (Ethiopian naturally fermented milk), butter, ghee and Ayib (Ethiopian cottage cheese) that are marketed through the informal channel (Reda, 2001).

In Sub Saharan countries the traditional sector, which is characterized by small herd size dominated by indigenous zebu breeds of low milk production with very little or no specialized inputs, is the dominant type of production system accounting to $70-80 \%$ of Africa's cattle population (Ibrahim and Olaloku, 2000). In Ethiopia, around 97\% of the annual milk production is accounted by the traditional milk production system (Felleke, 2003), which is likewise dominated by indigenous breeds. Most of the milk produced in the country is accordingly processed on-farm using traditional technologies that are generally not well understood. Most of the very few enterprises currently operating in and around the capital entirely depend on the traditional sector for their milk intake, while others depend on it for the majority of their intake. These underscore the importance of understanding the traditional sector in order to make improvement interventions.

Cows contribute to about $95 \%$ of the total annual milk produced by cows and camels at national level (CSA, 2010). In 2010, the cattle population was estimated at about 50.9 million (99.19\% indigenous, $0.72 \%$ hybrid and $0.09 \%$ pure exotic breeds). The female cattle population accounted for about $55 \%$ of the total. The large livestock population; the favorable climate for improved, high-yielding animal breeds; and the relatively animal disease-free environment make Ethiopia to hold a substantial potential for dairy development. In 2010, a total of 2940 million liters of milk was produced from about 9.6 million cows at national level. During the same year, dairying has created an estimated 
588,000 full-time on-farm jobs. However, Ethiopia is a net importer of dairy products with import values significantly exceeding export values. In five reference years, for instance, export values increased from about 73000 USD in 2005 to 123000 USD in 2009, while import values increased from about 5,6 million USD in 2005 to about 10,3 million USD in 2009 (a 4,7 million USD increment).

The importance of milk in the Ethiopian diet differs according to the farming system and the socio-cultural set-ups. Generally, in the lowlands especially where livestock keeping is the main occupation, milk is consumed by all groups of the society. In the highlands, the rural people are sedentary farmers raising both livestock and crops. The main part of their diet consists of cereals and legumes. Milk is used for rearing calves and children, and the surplus is soured for making different fermented milk products. The major ones include: Ergo, Ayib, butter (three types of butter can be distinguished namely Lega, Mekakelegna and Besal, which refer to fresh, semi-rancid and rancid), Nitir kibie (melted butter or ghee), Arrera (defatted sour milk, a by-product of butter-making and a raw material for Ayib-making) and Aguat (whey). The demand for milk and milk products is a function of several factors that include: population growth, seasonality of demand and supply, low per capita consumption and high transaction costs. The per capita milk consumption (about $17 \mathrm{~kg}$ ) for Ethiopia is much lower as compared to that for Africa (about 25kg), that recommended by World Health Organization (WHO) (200 liters), the $62.5 \mathrm{~kg}$ recommended by FAO (1990) as a minimum level to be kept for a balanced diet and the world's per capita average of about 100 liters/year (FAO, 2010).

In Ethiopia, milk marketing system is not well developed and for the majority of smallholder producers, access to market is limited. In year 2010, for instance, only less that 7 percent of the annual milk production is estimated to be marketed at national level. In 2009, there were 180 cooperatives involved in milk production and marketing in the entire nation, accounting for only $2 \%$ of the total number of agro-based cooperatives. In most of the cases, existing dairy cooperatives are operating in areas that are accessible to transportation and market. This means that a substantial amount of milk does not reach the market and a number of producers keep on producing at a subsistence level.

Post harvest losses of up to $40 \%$ of milk and its derivatives have been reported from milking to consumption (Felleke, 2003). Such loses are mainly attributed to mishandling in the dairy value chain from farm to fork. These include: contamination during milking and further handling coupled with long storage time at high tropical ambient temperature before consumption; deliberate adulteration of milk; substandard handling, transportation and distribution systems; inefficient processing technologies; inadequate fresh milk outlet; and spillage losses during milking. According to FAO (cited by ENA, 2004), the value of annual milk and dairy product losses due mainly to mishandling across five African and the Middle East countries (Kenya, Tanzania, Uganda, Ethiopia and Syria) is over 90 million USD. Reducing such losses and improving quality are effective ways of making more and safer milk available that benefits both producers and consumers.

Provision of milk and milk products of good hygienic quality is desirable from consumer health point of view. This is one reason why milk testing and quality control include hygiene as well as microbial qualities in addition to testing for fat content and heat stability (Giangiacomo, 2000). The consumption of raw milk and its derivatives is common in Ethiopia (Yilma, 2003), which is not safe from consumer health point of view as it may lead 
to the transmission of various diseases. Prior to the discovery and widespread adoption of pasteurization for instance, raw milk and its products were responsible for serious bacterial infections such as diphtheria, scarlet fever and tuberculosis (Spreer, 1998). The consumption of unpasteurized, incorrectly pasteurized or post pasteurization contaminated milk and its derivatives have been reported to cause illnesses (Duffy, Garvey \& Sheridan, 2002; Desenclos et al., 1996; Cody et al., 1999).

Consumers all over the world are increasingly concerned about the safety of their food in general and milk and milk products in particular. Therefore, quality should not be ignored at all stages of the dairy value chain from farm to table. As the bacterial quality of raw milk is important to product shelf-life, flavor and product yield, it is important that dairy enterprises should strive to obtain the highest quality raw material possible from their own farm as well as their suppliers. It is therefore essential to produce best quality raw milk in the dairy barn in order to manufacture milk products of not only acceptable quality but of high standard premium throughout the year.

Putting a functional quality control system in place is an important tool to bring about improvement in the dairy sector. However, in Ethiopia there is no a properly operational formal marketing and grading system that is geared towards relating quality of products to market price. Establishing a formal marketing system that relates quality to market price has a potential to enhance commercialization of the smallholder dairy sector. Such an approach provides an incentive for producers to supply products of good quality from nutritional as well as consumer health perspective.

\section{Study approach}

This chapter is essentially based on primary data collection using questionnaire, key informants, group discussions, personal observation and review of available literature. Data were generated from ten dairy potential areas in the Ethiopian highlands (Addis Ababa, Asella, Debre Birhan, Debre Zeit, Holetta, Sululta, Selale, Adama, Sheno, Jimma). A semi-structured questionnaire was used to collect information on hygienic practices at different stages of the dairy value chain from a total of 765 smallholder producers and 22 primary dairy cooperatives.

The milk quality assessment includes preliminary quality tests (specific gravity or milk density, clot-on-boiling and alcohol tests), while the microbial analysis include Aerobic Mesophilic Bacteria, Enterobacteriaceae, Coliform, and Yeast and mould counts.

\section{Hygienic conditions during production, processing, storage and marketing of milk and milk products}

\subsection{Milk production}

\subsubsection{Milking environment}

In Ethiopia, there is no standard hygienic condition followed by producers during milk production. The hygienic conditions are different according to the production system, adapted practices, level of awareness, and availability of resources. In most of the cases under smallholder condition, the common hygienic measures taken during milk production especially during milking are limited to letting the calf to suckle for few minutes and/or washing the udder before milking. The quality of the water used for 
cleaning purpose (to wash the udder, milk equipment, hands), however, is not secured (Yilma, 2003).

Maintaining the sanitary condition of milking area is important for the production of good quality milk. The drainage condition of the milking area, in this regard, is one of the most determinant factors. As observed during the current study, about $71 \%$ of the respondents had well drained and easy to clean barns. This is mainly attributed to the large proportion (80.4\%) of the respondents from all the study areas that used housed type of barn for their crossbred cows. Since housed and well built barns can drain easily, it has positive correlation with overall hygienic conditions of a given milking environment rendering the production of better quality milk. However, the barns owned by about $29 \%$ of the respondents were observed to be not well drained and difficult to clean, which leads to poor quality milk production. It is therefore important that producers consider appropriate drainage conditions of the milking environment as an integral part of production hygiene to ensure the supply of safe and good quality milk and its derivatives. It is also essential to implement a regular barn cleaning scheme. Although, about $87 \%$ of the respondents cleaned their barn on daily basis, about $9 \%$ of them cleaned only once or twice a week, and the remaining $4 \%$ did not clean at all.

\subsubsection{The cow and the milker}

Cleaning the udder of cows before milking is important since it could have direct contact with the ground, urine, dung and feed refusals while resting. Not washing udder before milking can impart possible contaminants into the milk. Milk is highly nutritious; therefore spoilage as well as pathogenic microorganisms present in the dust, urine, dung and feed refusals, once get access, can easily multiply and deteriorate the quality of milk making it unsafe for consumption and unfit for further processing. As observed during the present study, over 31 and $14 \%$ of the respondents owning local and crossbred dairy cows, respectively, do not wash the cow's udder before milking. They rather let calves to suckle before milking. Such practice, however, cannot replace washing. Producers should therefore make udder washing a regular practice in order to minimize contamination and produce good quality milk.

About 39 and $36 \%$ of the respondents owning local and crossbred milking cows, respectively, reported to not use towel at all, while about 10 and $20 \%$ of local and crossbred cow owners, respectively, responded to use collective towel to clean the udder of two or more milking cows. Such practice, in addition to its effect on milk quality, can lead to cross contamination of udder health problems of milking cows and related complications. In the current study about $27 \%$ of the respondents reported to have encountered udder health problems and over $18 \%$ of them reported the problem to have occurred more than twice a year. To reverse the situation, producers spent 650 birr per crossbred and 242 birr per local milking cows per year as treatment cost. The reported milk disposal from infected udders was estimated to amount to 1056 birr per crossbred and 560 birr per local cows. The use of individual towel and following essential cleaning practices during milking is important for the production of good quality milk and need be practiced by all producers.

Milkers, in addition to keeping good personal hygiene, should be in good health during milk operation. In this study, about 94 and $96 \%$ of the respondents reported to wash their hands before milking their local and crossbred cows, respectively. Covering hair and dressing gown during milking and handling of milk and milk products are important practices milkers need to obey, which weren't observed in any of the farms visited. 


\subsubsection{Milking utensils}

About 81 and $3.4 \%$ of the respondents used plastic and stainless equipment, respectively, while $6.6 \%$ of them used clay pot. Equipment used for milking, processing and storage determine the quality of milk and milk products. Producers need therefore pay particular attention for the type as well as cleanliness of milk equipment. Milking equipment should be easy to clean. Aluminum and stainless steel equipment are mostly preferred.

\subsubsection{Source of water used for cleaning}

Although, about $45 \%$ of the respondents reported to use tap water for cleaning purpose (udder, milk equipment and hand), about 19 and 16\% of them reported to use river and ground water, respectively, while the remaining about $20 \%$ reported to use water from either of the aforementioned sources (Fig. 1). Moreover, about $60 \%$ of the respondents that reported to use water from non tap sources neither boil nor filter it before use (Fig. 2). When water from non tap sources is used for cleaning purpose, it is important that producers should at least filter and heat treat it before use.

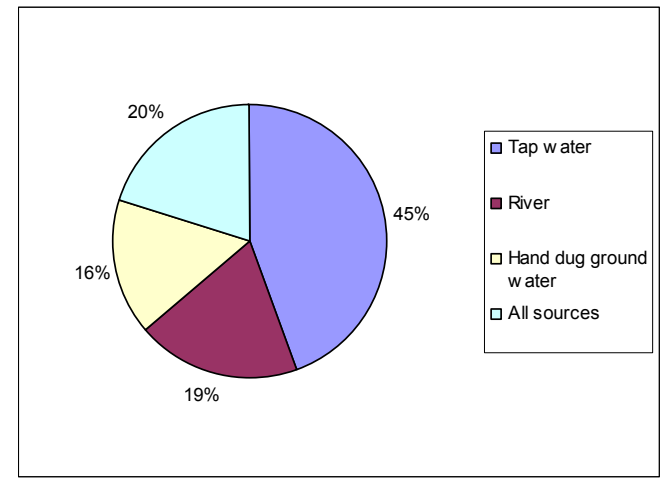

Fig. 1. Source of water used for cleaning purpose (cleaning udder, hands and milk equipment)

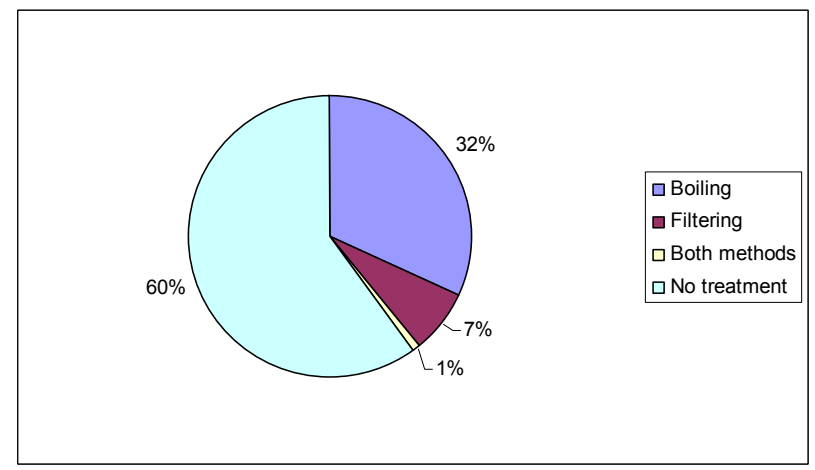

Fig. 2. Treatment of water from non tap sources before use (cleaning udder, hand, milk equipment) 


\subsection{Milk processing}

Although various traditional milk processing and storage equipment are used in different parts of Ethiopia, clay pot is the most commonly available and used. Though not regularly practiced, $74.4 \%$ of the producers process milk in to different products. Butter, Ergo and Ayib are the major fermented milk products, while clay pot is the most commonly used equipment under smallholder condition. Flow diagram of smallholder milk processing is presented in Fig. 3 and Fig. 4 depicts utilization of milk and milk products under smallholder condition. In Ethiopia, heating milk to sterilization temperature of above $100^{\circ} \mathrm{C}$ for 15 to 40 minutes followed by cooling and inoculation with known bacteria culture (starter) to achieve a controlled fermentation ( $\mathrm{O}^{\prime}$ Connor, 1994) is not practiced by smallholders.

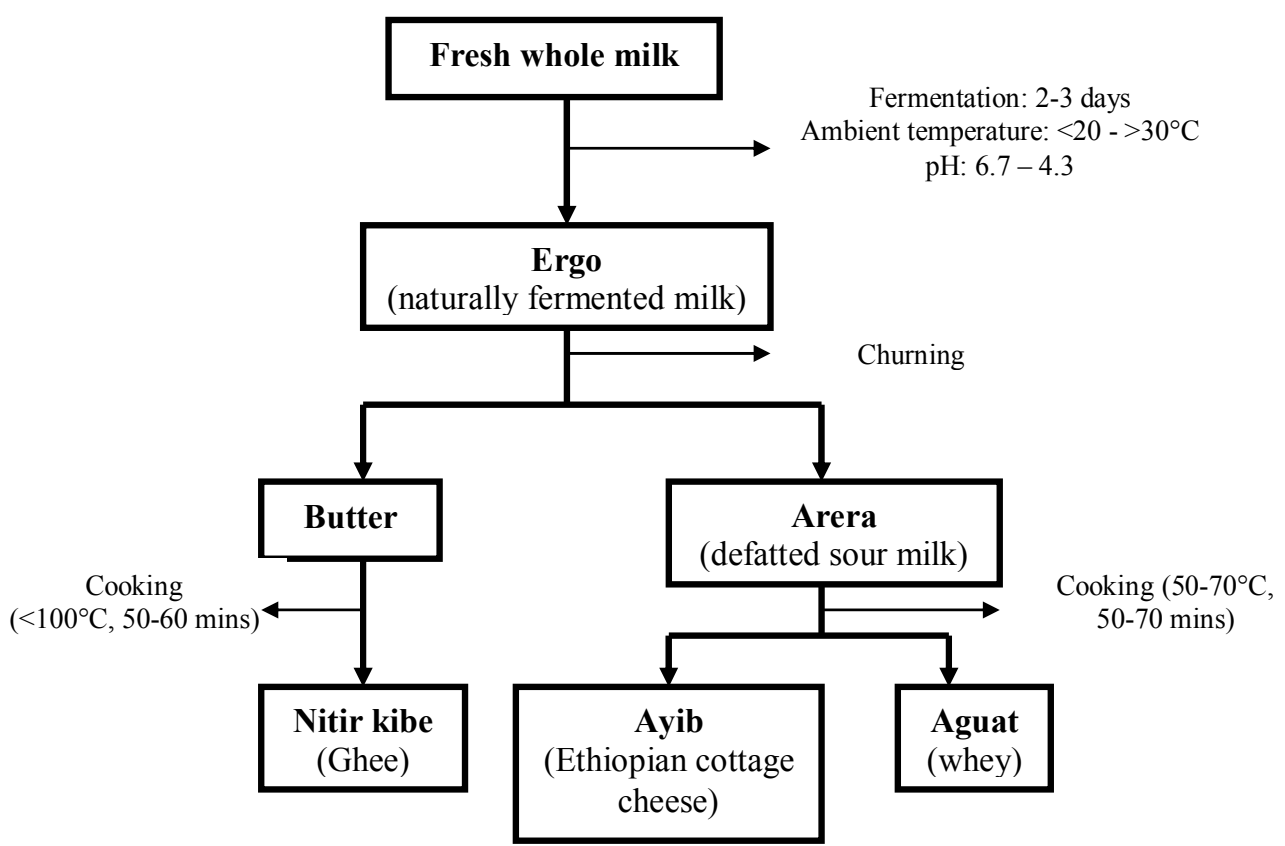

Fig. 3. Flow diagram of smallholder milk processing in the highlands of Ethiopia

Fermented milk is reported to have a storage stability of 15 to 20 days at a temperature of about 16 to $18^{\circ} \mathrm{C}$ ( $\mathrm{O}^{\prime}$ Connor, 1994). About $48 \%$ of the interviewees use clay pot for milk souring and/or churning for butter-making. In smallholder butter-making, microbial contamination can come from unclean surfaces, the butter maker and wash water. Packaging materials such as cups and leaves can also represent important sources of 
contamination. Although washing and smoking the churn reduce bacterial numbers, traditional equipments are often porous and difficult to clean, therefore can serve as a reservoir for many organisms ( $\mathrm{O}^{\prime}$ Connor, 1994). Over $61 \%$ of the respondents in the study areas reported to use clay pot as a churn and for storage. Ayib is made by heating Arera or sour skim milk in a clay pot or another material on a low fire to about $40-50^{\circ} \mathrm{C}$ (FAO, 1990; O'Connor, 1993). In the current study, over $59 \%$ of the respondents reported to use clay pot for Ayib-making and storage.

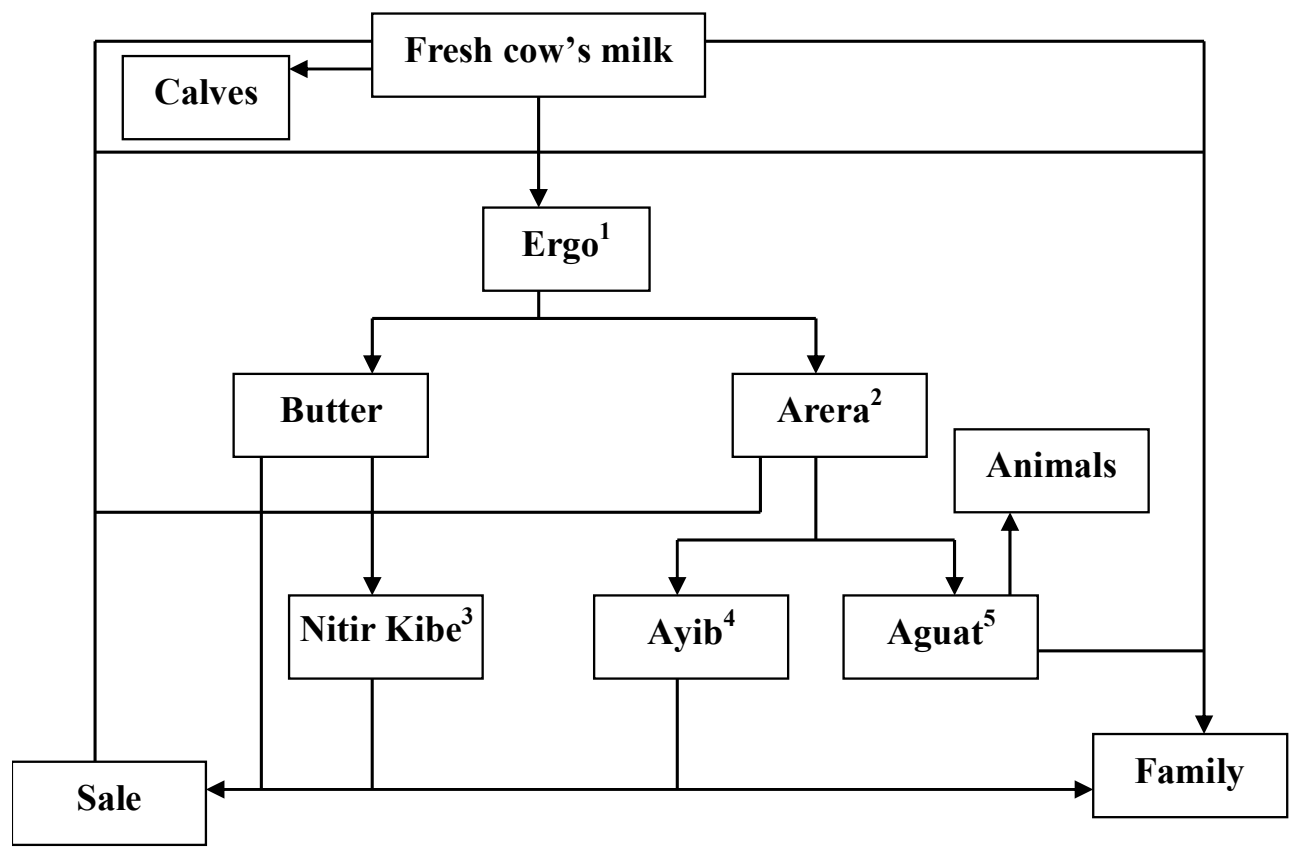

${ }^{1}$ Naturally fermented cow's milk, ${ }^{2}$ Defatted sour milk, ${ }^{3} \mathrm{Ghee},{ }^{4}$ Ethiopian cottage cheese, ${ }^{5}$ whey

Fig. 4. Flow scheme of smallholder utilization of milk and milk products

Milk cooperatives sell fresh whole milk directly without further processing as well as process into more shelf stable products whenever there is no market for fresh whole milk. Unlike smallholder producers, cooperatives use hand operated cream separator and therefore, milk makes the basis of processing in cooperative settings (Fig. 5). Although, smallholder and cooperative milk processing differs, both produce similar major marketable products: butter and Ayib. Cooperatives also use manual churn for buttermaking. 


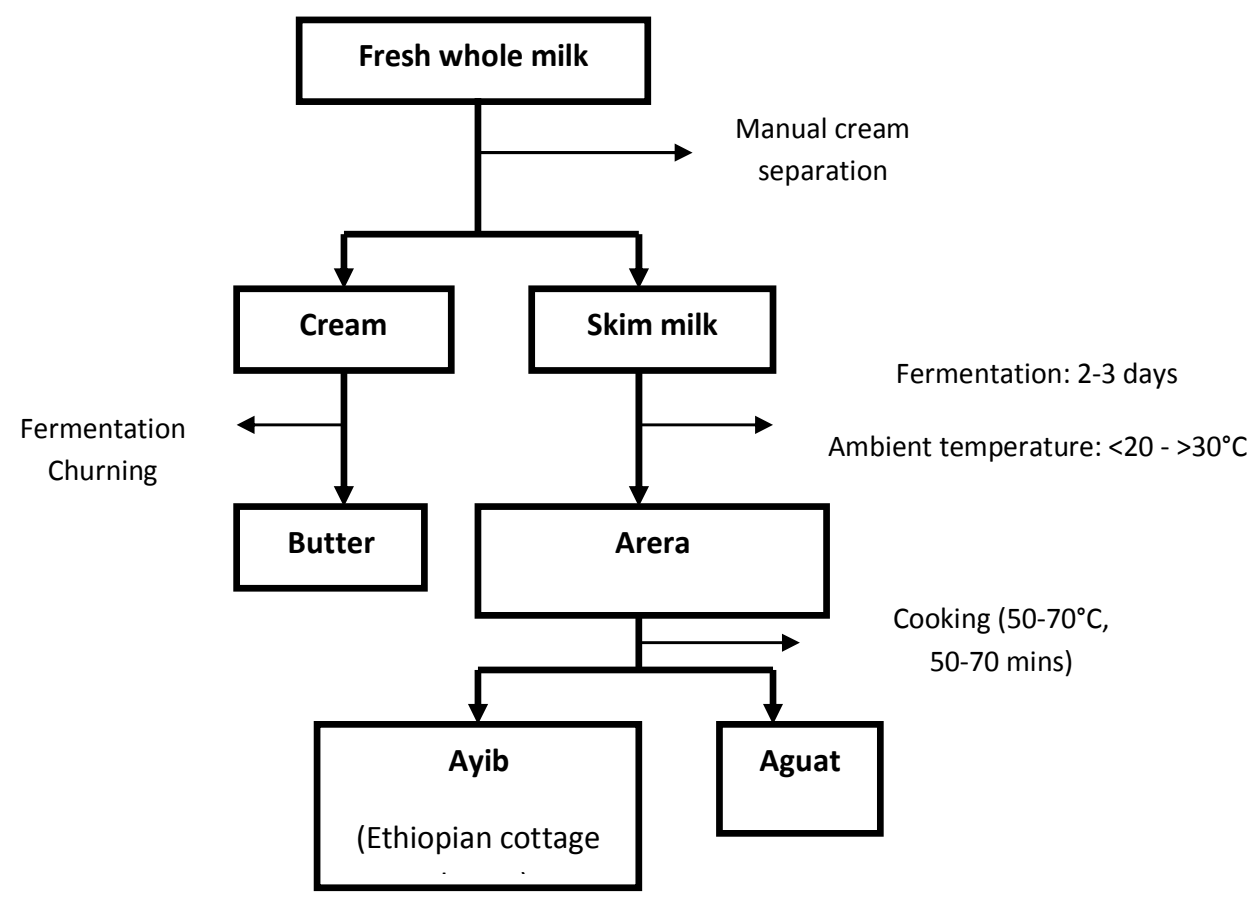

Fig. 5. Flow diagram of milk processing in cooperative centers in the highlands of Ethiopia

\subsection{Storage}

Milk products are generally more stable than fresh milk because they are more acidic and/or contain less moisture. Salt may also be added to milk products to prolong their shelf life. Applying principles of acidification, moisture reduction and salting (O'Mahony and Peters, 1987) can thus make milk products of good storage stability. All of the smallholder producers interviewed and about $82 \%$ of cooperatives stored their products at ambient temperatures. However, about $9 \%$ of the cooperatives have a refrigerator and the rest used cold water to store their products in cool conditions. Type of equipment used for different milk operations in the cooperative settings is presented in Table 1.

\begin{tabular}{|l|c|c|c|c|}
\hline \multirow{2}{*}{\multicolumn{1}{|c|}{ Purpose }} & \multirow{2}{*}{$\mathbf{N}$} & \multicolumn{3}{c|}{ Equipment used (frequencies, \%) } \\
\cline { 3 - 5 } & & Aluminum/Stainless steel & Plastic containers & Wooden containers \\
\hline Milk collection & 22 & 65.9 & 34.0 & - \\
\hline Milk storage & 22 & 76.2 & 23.8 & - \\
\hline Cream storage & 22 & 77.5 & 22.5 & - \\
\hline Butter storage & 22 & 55.0 & 15.0 & 30.0 \\
\hline Cheese storage & 22 & 88.2 & 11.8 & - \\
\hline
\end{tabular}

Table 1. Equipment used for different milk operations in cooperative settings 


\subsection{Marketing of milk and milk products}

There are basically two marketing systems in the central highlands of Ethiopia: formal and informal. In the formal system milk is collected at cooperative or private milk collection centers and transported to processing plants. In this system, there are somehow milk quality tests (alcohol and clot-on-boiling tests and density) up on delivery, and therefore the quality of milk is fairly secured. Producers supplying milk in this system pay a due emphasis in the production, storage and transportation of milk if their milk has to be accepted. In the informal system producers supply their surplus production to their neighbors and/or in local markets, either as liquid milk or in the form of butter and/or Ayib (O'Connor, 1992). In this system, the quality of milk and milk products is very poor mainly due to the prevailing situation where producers have limited knowledge of dairy product handling coupled with the inadequacy of dairy infrastructure such as electricity and clean water in the production areas.

In Ethiopia, there is no an operational hygienic regulation set for smallholder marketed dairy products. This indicates that the health of the dairy consuming community is not secured. This particularly holds true for Ayib, which is consumed with Enjera without farther treatment (Duteurtre, 1998). On open markets buyers of milk products practice organoleptic tests. The transaction of Ayib is particularly subject to such tests and it is uncommon that a buyer of Ayib is not tongue-testing the Ayib before buying it. This type of test is only partly associated with the effects of putrefactive microorganisms that can be detected by a simple tongue test. The presence of pathogenic microorganisms, however, cannot be detected by such tests.

There are reports that depict experiences of certain cooperatives around the Selale area (about 14\%) (Yilma, 1999) that had a rewarding mechanism through better payment for good quality milk supplied. Such an approach encourages cooperative member and nonmember farmers to be concerned about sanitary conditions during milk production and subsequent handling.

\subsection{Major milk quality related constraints}

Milk quality related constraints ranked during group discussions with dairy cooperatives are presented in Table 2. The major milk quality related constrains include: limited

\begin{tabular}{|l|c|}
\hline Constraints & Rank \\
\hline Limited awareness on hygienic handling & $1^{\text {st }}$ \\
\hline Shortage of capital & $1^{\text {st }}$ \\
\hline Lack of clean water & $3^{\text {rd }}$ \\
\hline Poor type of barn & $3^{\text {rd }}$ \\
\hline Hygiene of the milker & $5^{\text {th }}$ \\
\hline Lack of transport facilities & $6^{\text {th }}$ \\
\hline Mastitis (udder health problem) & $7^{\text {th }}$ \\
\hline Inappropriate materials used for milk production and handling & $8^{\text {th }}$ \\
\hline
\end{tabular}

Table 2. Major milk quality related problems ranked using pair-wise comparison during group discussions 
awareness on hygienic handling of milk and milk products, which could mainly be attributed to inefficient extension services; shortage of capital to purchase recommended equipment (milk containers, and processing and packaging materials); lack of clean water for sanitation purpose and poor condition of barn or milking area that is directly related to shortage of capital and limited awareness of its implication on milk quality.

\section{Quality of milk and milk products}

\subsection{Density and freshness of products}

Milk, at its normal state, has unique physico-chemical properties, which are used as quality indicators. The density of milk, among others, is commonly used for quality test mainly to check for the addition of water to milk or removal of cream. Addition of water to milk reduces milk density, while removal of cream increases it (O'Connor, 1994). The solid constituents of milk make milk an important food item from nutritional as well as processing point of view. Milk fat and protein are most important components of different varieties of most shelf stable milk products. All the 22 milk cooperatives used specific gravity test as an indicator of milk quality. The average specific gravity of 72 milk samples tested was 1.028 and 1.029 for Holetta and Selale areas, respectively (Fig. 6). These values fall within the range between 1.028 and 1.032 given to unadulterated milk (O'Connor, 1994). About $21 \%$ of the same samples checked with alcohol test were positive, while only $14 \%$ of the samples were positive for clot-on-boiling test. The results indicate that certain farmers deliver milk to collectors that has undergone fermentation that occurred either through long time elapsed between milking and delivery; mixing evening and morning milk; or use of insufficiently cleaned milk containers.

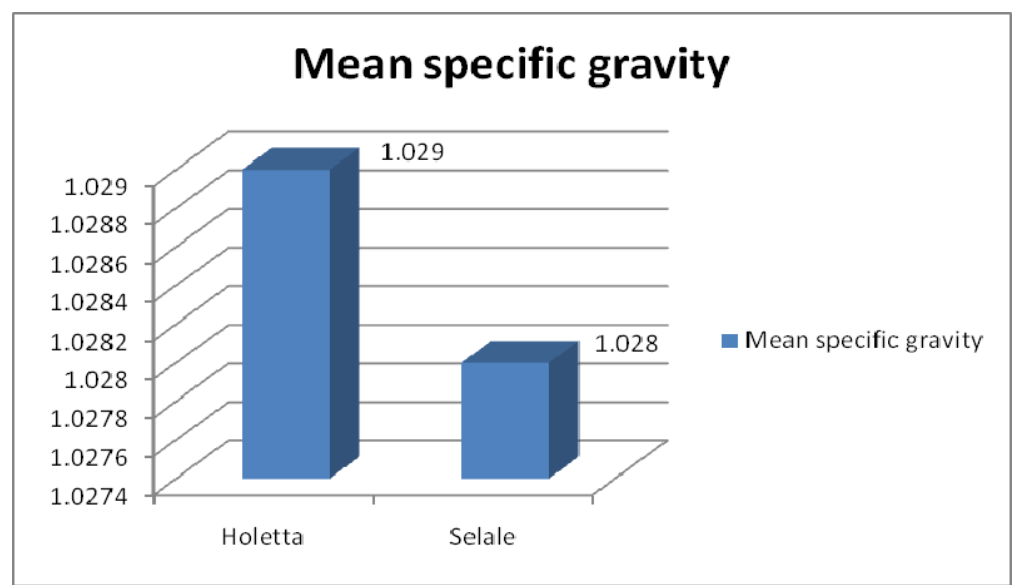

Fig. 6. Specific gravity/density of milk samples in Selale and Holetta areas

The mean $\mathrm{pH}$ values of whole milk ranged from 6.29 for Debre Birhan to 6.66 for Selale (data not presented). This variation and low $\mathrm{pH}$ may be attributed to the long time elapsed between milking and supply to collection centers. Three of the 24 samples of pasteurized milk checked with alcohol test were positive, while 5 of the samples were positive for cloton-boiling test. These results are consistent with the results of $\mathrm{pH}$ values observed for the 
same samples that ranged from the lowest 5.46 to the highest 6.14 with an overall mean value of 5.87. The relatively low $\mathrm{pH}$ of Ergo, ranging from 4.3 to 4.5 retards the growth of undesirable microorganisms, such as pathogens and spoilage bacteria, and enables its further storage (Gonfa et al., 2001).

\subsection{Microbial properties of milk and milk products}

The microbial content of milk indicates the hygienic levels during milking that include cleanliness of the milking utensils, proper storage and transport as well as the wholesomeness of the udder of the individual cow (Spreer, 1998). The most commonly used microbial quality tests for milk and milk products include determination of total bacterial count (TBC) or standard plate count (SPC) and colifom count (CC). Estimation of yeast and mould counts is also useful for evaluating sanitary practices (O'Connor, 1994). Microorganisms can enter milk via the cow, air, feeds, milk handling equipment and the milker. Once they get into the milk their numbers increase rapidly. It is therefore more effective to exclude microorganisms than trying to control their growth once they get access into the milk.

There are varieties of traditionally fermented dairy products in Ethiopia, for which the exact type of desirable lactic acid bacteria responsible for fermentation is unknown due mainly to uncontrolled and spontaneous fermentation. Most of these products are produced by smallholder producers where access to the required dairy infrastructure is limited. Results of the present study and selected reports of relevant earlier research efforts on the microbial properties of locally produced milk and milk products that have been carried out in different parts of the country are briefly summarized below.

\begin{tabular}{lccccc}
\hline Source & No of Obs. & TBC & Enterobacteriaceae & Coliform & YMC \\
\hline Overall mean & 630 & 8.35 & 5.10 & 4.53 & 8.32 \\
Whole milk & 135 & 9.10 & 5.49 & 4.58 & - \\
Ergo & 105 & 9.49 & 4.95 & 4.51 & 8.38 \\
Butter & 105 & 6.67 & 4.95 & 4.58 & 8.32 \\
Arera & 75 & 9.35 & 4.94 & 4.65 & - \\
Ayib & 105 & 7.01 & 4.84 & 4.42 & 8.26 \\
Skim milk & 105 & 9.37 & 5.34 & 4.44 & - \\
\hline
\end{tabular}

TBC: Total Bacterial Count; YMC: Yeast and Mould Count

Table 3. Overall bacterial and yeast and mould counts (log10) per $\mathrm{ml} / \mathrm{g}$ of milk and milk product samples collected from different sources (sites and producer groups)

Although there are slight variations between sample sources (locations/producer groups) in microbial counts, the figures observed in the present study are generally much higher than acceptable limits (Table 3). TBC is generally high in samples of whole milk, Ergo and skim milk. Counts of Enterobacteriaceae and coliform counts are higher than acceptable limits: Enterobacteriaceae $<1$ and coliform $<10 \mathrm{cfu} / \mathrm{ml}$ for pasteurized milk, and coliform $<100$ $\mathrm{cfu} / \mathrm{ml}$ for raw milk intended for direct consumption (Council Directives 92/46/EEC, 1992). The higher count in milk indicates substandard hygienic conditions practiced during production and subsequent handling. The high count in fermented milk products, however, can be partly explained by lactic acid bacteria. 


\subsubsection{Whole milk}

Mean total bacterial counts ranged from $10.12 \mathrm{log} \mathrm{cfu} / \mathrm{ml}$ of milk collected from Jimma to $8.30 \log \mathrm{cfu} / \mathrm{ml}$ of milk sampled from Debre Zeit and Adama with the average value being $9.10 \mathrm{log} \mathrm{cfu} / \mathrm{ml}$. These values exceed the acceptable value of $10^{5} \mathrm{cfu} / \mathrm{ml}$ for milk in most European counties (Council Directives 92/46/EEC, 1992; IFCN, 2006). Mean counts of Enterobacteriaceae were greater than $5 \mathrm{log} \mathrm{cfu} / \mathrm{ml}$ and coliform counts greater than $4 \log$ $\mathrm{cfu} / \mathrm{ml}$ of milk sampled from all study sites.

In Ethiopia, milking animals are kept with the rest of the stock in a shade or enclosure during the night. Milking is done in the shade, grazing field in front of the homestead, or under a tree. However, as these areas are not generally kept clean enough, milking cows usually become soiled with dung and urine. Moreover, cleaning of the udder and hind quarters of the cow is not a common practice. This coupled with the unhygienic cleaning and handling of milk containers result in microbial contamination of milk (Tola, 2002; Gonfa et al., 2001).

According to an earlier report, milk samples collected form smallholder producers in East Wollayta (Southern Ethiopia) had average total microbial count of $7.60 \mathrm{log} \mathrm{cfu} / \mathrm{ml}$ (Tola, 2002). A total bacterial count ranging from 6.0 to $8.8 \mathrm{log} \mathrm{cfu} / \mathrm{ml}$ in which $15 \%$ of the samples had a count equal or above $7.7 \mathrm{log} \mathrm{cfu} / \mathrm{ml}$ in raw milk samples in Southern Ethiopia was also reported (Beyene, 1994). In another report, milk sampled from most of the dairy cooperatives operating in the country had total bacterial count of $10^{8} \mathrm{cfu} / \mathrm{ml}$ (Francesconi, 2006). These values are much higher than the acceptable limits in different countries $\left(10^{4}\right.$ to $\left.10^{5} \mathrm{cfu} / \mathrm{ml}\right)(\mathrm{IFCN}, 2006)$. This implies that the sanitary conditions in which milk has been produced and handled are substandard subjecting the product to microbial contamination and multiplication. It is indicated that total bacterial count is a good indicator for monitoring the sanitary conditions practiced during production, collection, and handling of raw milk (Chambers, 2002). A good instance worth mentioning is a reduced total bacterial count observed in milk sampled from farmers who received training on hygienic milk production and handling, and who used recommended milk containers as compared to that produced by the traditional milk producers (control) (Tola, 2002; Nebiyu, 2008; Sintayehu et al., 2008). A similar result was also reported for large-scale producers and research centers where there is a better access to dairy facilities as compared to small-scale producers (Yilma and Faye, 2006).

According to a report from Southern Ethiopia, raw cow's milk sampled from smallholder producers contained coliform counts of about $4.46 \mathrm{log} \mathrm{cfu} / \mathrm{ml}$ (Tola, 2002). Similar counts were also observed in raw milk sampled from smallholder producers in the central highlands of Ethiopia (Yilma and Faye, 2006; Yilma et al., 2007a). Higher counts of different species of Enterobacteriaceae were reported with Escherichia coli being the most abundantly isolated species (Yilma et al., 2007a), which is a good indicator of recent fecal contamination (Bintsis et al., 2008).

In a study focused on the identification of major bacterial species found in milk as it comes from the udder, it is reported that Micrococci represent the largest proportion followed by Streptococci and rods (O'Connor, 1994). In a separate study, Staphylococci and Micrococci are reported to be the most common udder-specific bacteria of environmental origin in milk samples taken directly from the udder (Godefaye and Molla, 2000). 


\begin{tabular}{lcccccc}
\hline Producer & Whole milk & Ergo $^{*}$ & Butter & Arera & Ayib & Skim milk \\
\hline Total bacteria & & & & & & \\
Smallholder farmers & 8.87 & 9.48 & 6.86 & 9.35 & 7.16 & - \\
Cooperatives & 9.49 & 9.54 & 6.14 & - & 6.51 & 9.25 \\
$\begin{array}{l}\text { Overall mean } \\
\text { Enterobacteria }\end{array}$ & 9.10 & 9.49 & 6.67 & 9.35 & 7.00 & 9.25 \\
Smallholder farmers & 5.51 & 4.94 & 4.97 & 4.94 & 4.85 & - \\
$\quad$ Cooperatives & 5.45 & 4.98 & 4.90 & - & 4.82 & 5.30 \\
Overall mean & 5.48 & 4.95 & 4.95 & 4.94 & 4.84 & 5.30 \\
$\quad$ Coliforms & & & & & & \\
Smallholder farmers & 5.59 & 4.48 & 4.60 & 4.65 & 4.44 & - \\
Cooperatives & 4.54 & 4.61 & 4.53 & - & 4.37 & 4.37 \\
Overall mean & 4.58 & 4.51 & 4.58 & 4.65 & 4.42 & 4.37 \\
Yeast and mould & & & & & & \\
Smallholder farmers & - & 8.39 & 8.34 & - & 8.26 & - \\
Cooperatives & - & 8.34 & 8.27 & - & 8.27 & - \\
Overall mean & - & 8.38 & 8.32 & - & 8.26 & - \\
\hline
\end{tabular}

*Ergo refers to fermented whole milk for smallholder farmers, while it refers to fermented skim milk for cooperatives

Table 4. Microbial count $(\log 10)$ per $\mathrm{ml} / \mathrm{g}$ of milk and milk products categorized by sample source (producer type)

Total aerobic plate counts were $1.1 \times 10^{5}, 4 \times 10^{6}$ and $1.9 \times 10^{8} \mathrm{cfu} / \mathrm{ml}$ respectively for milk samples taken from milking bucket, storage container and processing plant on arrival (Godefaye and Molla, 2000). In the same study, mean coliform counts were reported to range from $1.3 \times 10^{4} \mathrm{cfu} / \mathrm{ml}$ (storage container) to $7.1 \times 10^{6} \mathrm{cfu} / \mathrm{ml}$ (on arrival at the processing plant). The hygienic quality of the milk from a collection center was poor with a mean total bacterial count of $1.3 \times 10^{7} \mathrm{cfu} / \mathrm{ml}$. In another study, $4 \times 10^{7}$ and $1 \times 10^{9} \mathrm{cfu} / \mathrm{ml}$ total microbial counts were reported as lowest and highest values, respectively for raw milk samples at a processing plant in Addis Ababa. Of the total counts in raw milk, psychrophilic, thermoduric and thermophilic organisms made up $98.1,1.4$ and $0.5 \%$, respectively.

\subsubsection{Ergo - Naturally fermented milk}

Ergo is made by natural fermentation of milk under ambient temperature, without the addition of starter cultures (Assefa et al., 2008). The use of a portion of ergo from a previous batch as a starter in highland areas where ambient temperature is relatively low is reported (Kassa, 2008). This practice is technically adapted to overcome the effect of low ambient temperature, which slows down the growth of lactic acid bacteria (LAB) in the absence of starter culture thus prolongs the fermentation time. The temperature and duration of incubation varies from place to place depending on the prevailing environmental conditions. According to a previous report, five LAB genera were identified from Ergo that include Lactobacillus, Lactococcus, Leuconostoc, Entrococcus and Streptococcus (Assefa et al., 2008). They also indicated the LAB species identified in Ergo to be Streptococcus thermophilus, Strep. acidominus, Enterococcus faecalis var. liquefaciens, Strep. bovis, Strep. mitis, Strep. agalactiae, Lactococcus cremoris, Leuconostoc dextranicum, Leuc. lactis, Lactobacillus xylosus and 
Lact. lactis. The isolation of similar genera, and Micrococci and coliforms, which are present in low numbers was also reported (Gonfa et al., 2001). An average LAB count of $7.68 \mathrm{log}$ $\mathrm{cfu} / \mathrm{ml}$ for Ergo samples collected from different producers in Addis Ababa and major cities around Addis Ababa was also reported (Yilma and Faye, 2006).

$\mathrm{LAB}$ are reported to have antimicrobial activities. The use of different LAB species to create a stationary phase for Staphylococcus aureus and a higher density of LAB in modeled starter culture could result in complete inhibition of the bacterium (Le Marc et al, (2009). Another report also indicated that $12 \mathrm{LAB}$ isolates from Ergo that include Lactobacillus plantarum, Lactococcus lactic ssp cremoris, Lactococcus lactic ssp lactic, Lactobacillus acidophyilus, Leuconostoc lactic, Pediococcus pentosace and Pediococcus sp. have antimicrobial activities against different pathogenic microbes including Shigella flexinery, Salmonella typhi, Escherichia coli and Staphylococcus aureus (Assefa et al., 2008).

TBC of Ergo was generally high ranging from $7.71 \mathrm{cfu} / \mathrm{ml}$ in samples collected from Sheno to about $10 \mathrm{cfu} / \mathrm{ml}$ in samples from Jimma. Average Enterobacteriaceae and coliform counts were greater than $4 \mathrm{cfu} / \mathrm{ml}$ of Ergo sampled from all study sites with differences between the lowest and highest counts ranging from 0.25 to $0.37 \mathrm{cfu} / \mathrm{ml}$.

Mean yeast and mould counts observed in the current study exceeded $8 \mathrm{cfu} / \mathrm{ml}$ of Ergo sampled from all the sites considered. However, a lower value $\left(2 \times 10^{5} \mathrm{cfu} / \mathrm{ml}\right)$ was reported (Gonfa et al., 2001). Yeast and mould count of up to $4.6 \mathrm{log} \mathrm{cfu} / \mathrm{ml}$ of fermented milk sampled from Southern Ethiopia was also reported (Beyene, 1994). These values are much higher than the acceptable value ( $<10 \mathrm{cfu} / \mathrm{gm}$ for yoghurt) (Mostert and Jooste, 2002). The presence of different species of yeast in milk and its products may result in the spoilage of the product or conversely could contribute to the enhancement of the flavor of fermented milk, since different yeast species are able to assimilate different milk substrates (Gadaga et al., 2000). Bacterial species namely Klebsiella pneumoniae, Klebsiella oxytoca, Enterobacter cloacae, Citrobacter freundii and Enterobacter sakazakii were isolated from Ergo samples collected from smallholder producers in the central Ethiopia (Yilma et al., 2007a). Coliform count averaging at $6.57 \mathrm{log} \mathrm{cfu} / \mathrm{ml}$ was reported for Ergo samples (Yilma and Faye, 2006). Lower values were also observed in which $75 \%$ of the samples showed coliform count less than $4.4 \log \mathrm{cfu} / \mathrm{ml}$ (Beyene, 1994). However, the same author also reported TBC of greater than $8.6 \log \mathrm{cfu} / \mathrm{ml}$ for $3 / 4^{\text {th }}$ of fermented milk samples collected from three villages in Southern Ethiopia and coliform counts of higher than $4.4 \log \mathrm{cfu} / \mathrm{ml}$ in $15 \%$ of two fermented milk varieties.

The common traditional milk processing techniques involve smoking of processing utensils using embers of Olea africana. This smoking practice is reported to be beneficial to keep better quality of Ergo through its inhibitory effect on spoilage and pathogenic organisms. For instance, the inhibitory effect of smoking on Listeria monocytogenes was reported (Ashenafi, 1994). The effect of lower $\mathrm{pH}$ of Ergo in controlling the proliferation of undesirable microorganisms is more effective after 24 hours of incubation. However, at this time, the ergo is considered to be too sour for direct consumption since ergo coagulates within 24 hours and preferably consumed at this time for its good flavor (Ashenafi, 2006). Accordingly, the same author recommended that milk should be boiled beforehand and a small amount of 3-days-old Ergo that is normally free from pathogens but contains enough $\mathrm{LAB}$ should be inoculated to initiate fermentation. 


\subsubsection{Kibe - Traditional butter}

Different studies on various aspects of traditional butter-making in Ethiopia have been undertaken in different parts of the country. Traditional butter-making is based on sour milk that has been accumulated over a few days commonly in a clay pot. Once the amount of the accumulated sour milk justifies churning, the sour milk is mixed thoroughly by using a wooden stick with 3 to 5 finger-like projections at one end (mesbekia in amahric) then churned using different techniques until butter granules are formed.

Mean total bacterial counts ranged from $6.18 \mathrm{cfu} / \mathrm{g}$ in butter samples collected from Selale area to $7.25 \mathrm{cfu} / \mathrm{g}$ in samples from Sululta. These values are higher than the acceptable limit of $5 \times 10^{4} \mathrm{cfu} / \mathrm{g}$ (Mostert and Jooste, 2002). Average Enterobacteriaceae and coliform counts were greater than $4 \mathrm{cfu} / \mathrm{g}$ of butter sampled from all study sites both of which are higher than the acceptable value of $<10 \mathrm{cfu} / \mathrm{g}$ (Mostert and Jooste, 2002). Mean yeast and mould counts observed in the current study exceeded $8 \mathrm{cfu} / \mathrm{g}$ of butter sampled from all the sites considered.

TBC of $3.15 \times 10^{7}$ and the presence of high variability among samples depending on the sources were reported (Mamo, 2007). Samples collected from open markets and rural producers, for instance, had higher counts as compared to that obtained from dairy farms and urban producers. Coliform counts ranging from 1.92 to $4.5 \mathrm{log} \mathrm{cfu} / \mathrm{gm}$ of butter are reported (Mamo, 2007; Asfaw, 2008; Yilma et al., 2007a). These differences could be attributed to the wide variation in hygienic handling during milking, processing, storage and transport to market. Klebsiella pneumoniae, Klebsiella oxytoca, Enterobacter cloacae, Citrobacter freundii, and Esherichia coli were isolated from ergo samples collected in the central Ethiopia (Yilma et al., 2007ab), and these microbes are considered to be pathogenic and spoilage (Walstra et al., 2006). On the other hand, yeast and mould counts ranging between 4.3 and $6.86 \mathrm{log} \mathrm{cfu} / \mathrm{g}$ of butter sampled from Wollayta area are reported (Asfaw, 2008). Average yeast and mould count of $4.5 \times 10^{7} \mathrm{cfu} / \mathrm{g}$ of butter was also reported (Mamo, 2007). Higher values are observed (Yilma et al., 2005) that varied depending on the type of producer where lower counts were observed for butter sampled from research centers and small-scale producers than that from large-scale producers. TBC of fresh butter sampled from rural and public butter markets in Addis Ababa ranged from $6.2 \mathrm{x}$ $10^{4}$ to $1.86 \times 10^{8}$ per gram of butter and coliforms were found in all samples that indicate poor hygienic practices (ILCA, 1992). These high deviations from the acceptable value of $10 \mathrm{cfu} / \mathrm{gm}$ (Mostert and Jooste, 2002) indicate substandard handling conditions at all stages in the milk chain.

\subsubsection{Arera - Defatted sour milk}

Average counts of total bacteria, Enterobacteriaceae and coliforms were greater than 9, 4.7 and $4.2 \mathrm{cfu} / \mathrm{ml}$, respectively of Arera sampled from all study sites both of which are higher than the acceptable value of $<10 \mathrm{cfu} / \mathrm{gm}$ (Mostert and Jooste, 2002). Traditionally produced Arera sampled from Wollayta area had total bacterial count of about $9 \log \mathrm{cfu} / \mathrm{ml}$ (Nebiyu, 2008). The same author also reported coliform count of $4.86 \mathrm{log} \mathrm{cfu} / \mathrm{ml}$. Different species of bacteria were identified in Arera samples collected during both dry and wet seasons, which include: Klebsiella pneumoniae, Klebsiella oxytoca, Enterobacter cloacae, Enterobacter sakazakii, Esherichia coli and some species of Salmonella (Yilma et al., 2007a). 


\subsubsection{Ayib - Ethiopian cottage cheese}

Mean TBC ranged from $6.46 \mathrm{cfu} / \mathrm{g}$ in Ayib samples collected from Arsi and Selale area to $7.87 \mathrm{cfu} / \mathrm{g}$ in samples from Sululta with the overall mean being $7.01 \mathrm{cfu} / \mathrm{g}$. Average Enterobacteriaceae and coliform counts were greater than $4 \mathrm{cfu} / \mathrm{g}$ of Ayib sampled from all study sites. Mean yeast and mould counts observed in the current study exceeded $8 \mathrm{cfu} / \mathrm{g}$ of Ayib sampled from all the sites considered.

Ayib samples contained high numbers of mesophilic bacteria, Enterococci, and yeasts (Ashenafi, 2002). The author also reported aerobic mesophilic bacterial counts of over $10^{8} \mathrm{cfu} / \mathrm{g}$ for more than $90 \%$ of the samples collected in Southern Ethiopia. Works undertaken to identify bacterial species in ayib samples reported Klebsiella pneumoniae, Klebsiella oxytoca, Enterobacter cloacae (Yilma et al., 2007b), Staphylococcus aureus and Bacillus cereus (Ashenafi, 2002).

Several earlier works carried out in different parts of the country reported coliform counts of ayib samples that ranged between $2 \log \mathrm{cfu} / \mathrm{gm}$ (Ashenafi, 2002, 2006) and $5.68 \mathrm{log} \mathrm{cfu} / \mathrm{gm}$ (Yilma et al., 2005) with differences being a function of source of samples and handling conditions. Coliform counts varied among samples collected from different producers where samples from research centers had lower coliform counts $(4.85 \mathrm{log} \mathrm{cfu} / \mathrm{gm})$ as compared to samples from large-scale (5.68 log cfu/gm) and small-scale (5.48 log cfu/gm) farms showing variations in the hygienic conditions practiced among the different producers (Yilma et al., 2005). However, in all cases values are higher than the acceptable level of $<10 \mathrm{cfu} / \mathrm{gm}$ (Mostert and Jooste, 2002) indicating the poor hygienic conditions practiced during processing and handling.

Ayib samples collected from an open market in Awassa showed high numbers of mesophilic bacteria, enterococci and yeasts (Table 19). More than $90 \%$ of the samples had aerobic mesophilic counts of $\geq 10^{8} \mathrm{cfu} / \mathrm{g}$ while more than $75 \%$ of the samples had yeast counts of $\geq$ $10^{7} \mathrm{cfu} / \mathrm{g}$, and over $85 \%$ contained Enterococci in numbers of $\geq 10^{7} \mathrm{cfu} / \mathrm{g}$. The majority of the samples had mould and lactic acid bacteria counts of $10^{5} \mathrm{cfu} / \mathrm{g}$ or higher, spore-formers of about $10^{4}$ and psychrotrophs of about $10^{6} \mathrm{cfu} / \mathrm{g}$. Over $32 \%$ had coliform counts of more than $10^{2} / \mathrm{g}$ and about $27 \%$ contained fecal coliform loads of more than $10^{2} / \mathrm{g}$. Bacillus cereus and Staphylococcus aureus were isolated in $63 \%$ and $23 \%$ of the samples, respectively, but at low numbers (102 to $\left.10^{3} \mathrm{cfu} / \mathrm{g}\right)$ (Ashenafi, 1990).

\subsubsection{Domestic commercial pasteurized milk}

Mean total bacterial counts ranged from 6.60 to $7.54 \log _{10} \mathrm{cfu} / \mathrm{ml}$ of domestic pasteurized milk collected from different kiosks and supermarkets in Addis Ababa with the average value being $7.28 \log _{10} \mathrm{cfu} / \mathrm{ml}$ (Table 5). Mean counts of coliform bacteria and Enterobacteriaceae were 2.87 and $3.69 \log _{10} \mathrm{cfu} / \mathrm{ml}$, respectively. These values are much higher than the acceptable values. As presented in microbiological safety limits for major milk products in community legislation in force by the European Commission, the maximum limit for total bacterial and coliform counts in pasteurized milk intended for drinking is $5 \times 10^{5}$ and $5 \mathrm{cfu} / \mathrm{ml}$, respectively, while Enterobacteriaceae count should be $<1 \mathrm{cfu} / \mathrm{ml}$ and pathogenic microorganisms should not be detected in $25 \mathrm{ml}$ of the product (Council Directives 92/46 EEC, 1992).

The pasteurized milk samples considered in the present study were between 5 to 2 days before the expiry date as indicated on the packaging materials. Although, the high total 
bacterial count observed in the current study can partly be attributed by lactic acid bacteria, which can be explained by the low mean $\mathrm{pH}$ value of 5.87, the higher counts of coliform bacteria and Enterobacteriaceae imply that there was a problem either in the pasteurization process or there occurred post pasteurization contamination during packaging. Protection from post-pasteurization contamination before the milk product is packaged is a critical factor in achieving a safe food. Ingredients added after pasteurization of the milk portion of the food can be a source of pathogens. The control of potential sources of contamination can be addressed by following production practices based on Good Manufacturing Practices.

Pasteurized milk had mesophilic aerobic counts of $7 \times 10^{5} \mathrm{cfu} / \mathrm{ml}$ as it left the pasteurizing unit (Mahari and Gashe, 1990). According to the same source, psychrophilic, thermoduric and thermophilic organisms constituted 53.0, 39.5 and 7.5\%, respectively and the isolates belonged mostly to the genera Bacillus, Streptococcus, Lactobacillus, Arthrobacter, Alcaligenes, Aeromonas and Pseudomonas. Cocci were more predominant than rod-shaped bacteria and of the rod-shaped bacteria $73 \%$ were gram-negative. As indicated by the same authors, utensils holding the raw and pasteurized milk and plastic sheets used for bagging the pasteurized milk were reported to contribute for the high bacterial count, which were either thermoduric or thermophilic.

\begin{tabular}{lcccc}
\hline Pasteurized milk sample* $^{*}$ No. of obs. & \multicolumn{3}{c}{ Count, Log10 cfu/ml } \\
\cline { 3 - 5 } & & TBC & CC & EntC \\
\hline A & 4 & 7.28 & 3.18 & 3.58 \\
B & 4 & 6.60 & 3.28 & 3.94 \\
C & 4 & 7.47 & 3.26 & 4.26 \\
D & 4 & 7.37 & 2.34 & 3.63 \\
E & 4 & 7.54 & 2.77 & 3.68 \\
F & 4 & 7.42 & 2.40 & 3.05 \\
Overall mean & 24 & 7.28 & 2.87 & 3.69 \\
\hline
\end{tabular}

*Different letters represent different brands of pasteurized milk marketed in Addis Ababa; TBC: Total Bacterial Count; CC: Coliform Count; EntC: Enterobacteriaceae Count; cfu/ml: Colony Forming Units per millilitre

Table 5. Microbial quality of domestic commercial pasteurized milk sampled from different kiosks and supermarkets in Addis Ababa

\section{Critical control points in the milk chain}

As with hygiene and food safety, the issue of quality has been growing prominently in recent years and the optimum approach to these two areas is remarkably similar. Providing quality assured products to the consumer has traditionally relied on quality control of finished products, that is, a set of procedures to test and analyze the product to ensure it conforms to the required specification. This approach has drawbacks that include incidents of food poisoning in spite of quality control procedures, less effective as microorganisms are not evenly distributed in products, and high cost of rejected products as the quality control is based solely on finished product testing. This is one reason why, developments in quality management have focused on the prevention of defects in the first place (through effective design and hazard elimination) rather than trying to measure defects once the product has been manufactured. Applying this approach to hygiene has led to the development of preventive 
Quality Assurance (QA) systems. Hazard Analysis and Critical Control Point (HACCP) in particular is employed in the identification of stages in the food chain where spoilage as well as pathogenic microorganisms can enter, survive and proliferate in the food and managing these as the key control strategy rather than relying on testing end products (IDF, 1994).

In the Ethiopian smallholder context, six Critical Control Points (CCPs) where milk and milk products can be contaminated can be identified (Fig. 7). These include:

i. During milk production: During milking, contamination can come from the cow, the milker, utensils used for milking, storage and filtering the milk, and the barn or the milking environment.

ii. During fermentation: Milk containers used for fermentation, wash water of poor quality used, ingredients added with the intention of improving the flavor of the final product can represent potential sources of contamination.

iii. During churning (butter-making): Churns and warm water added to facilitate the churning process (speed-up butter recovery) can be possible sources of contamination.

iv. During Ayib-making: Low cooking temperatures that may not be enough to kill spoilage as well as pathogenic microorganisms can be considered as an important point for the poor quality of the final product. Other potential sources of microbial contamination include: materials used for Ayib-making, other utensils such as that used for draining the whey or ladling out the Ayib, and filtration.

v. Packaging/storage of butter and Nitir Kibe/ghee: Potential sources of contamination here include: product container/packaging, high keeping temperature, and poor personal hygiene of people handling the product.

vi. Packaging/storage of Ayib: Potential sources of contamination here are similar with that under v above.

CCPs at dairy cooperatives are summarized in Fig. 8:

i. The milk/reception: The raw material milk can be contaminated via the cow; the milker; the barn; utensils used for milking, filtering, storage (at farm and cooperative center) and transport.

ii. During cream separation: Contamination at this point can come from the separator, wash water, personnel, and environment.

iii. During fermentation of skim milk: Containers used for fermentation, poor quality wash water, personnel and the environment represent potential sources of contamination.

iv. During churning (butter-making): Contamination at this point can come from the churn (container), personnel, wash water, and environment.

v. During Ayib-making: Low cooking temperatures that may not be enough to kill spoilage as well as pathogenic microorganisms can be considered as an important point for the poor quality of the final product. Other potential sources of contamination include: materials used for Ayib-making, other utensils such as that used for draining the whey or ladling out the Ayib, and filtration.

vi. Packaging/storage of butter: Potential sources of contamination here include: product container/packaging, high keeping temperature, poor personal hygiene of people handling the product, and environment.

vii. Packaging/storage of Ayib: Potential sources of contamination here are similar with that under vi above.

The aforementioned critical points of contaminations can be considered for making improvement interventions. 
Microbial Properties of Ethiopian Marketed Milk and Milk Products and

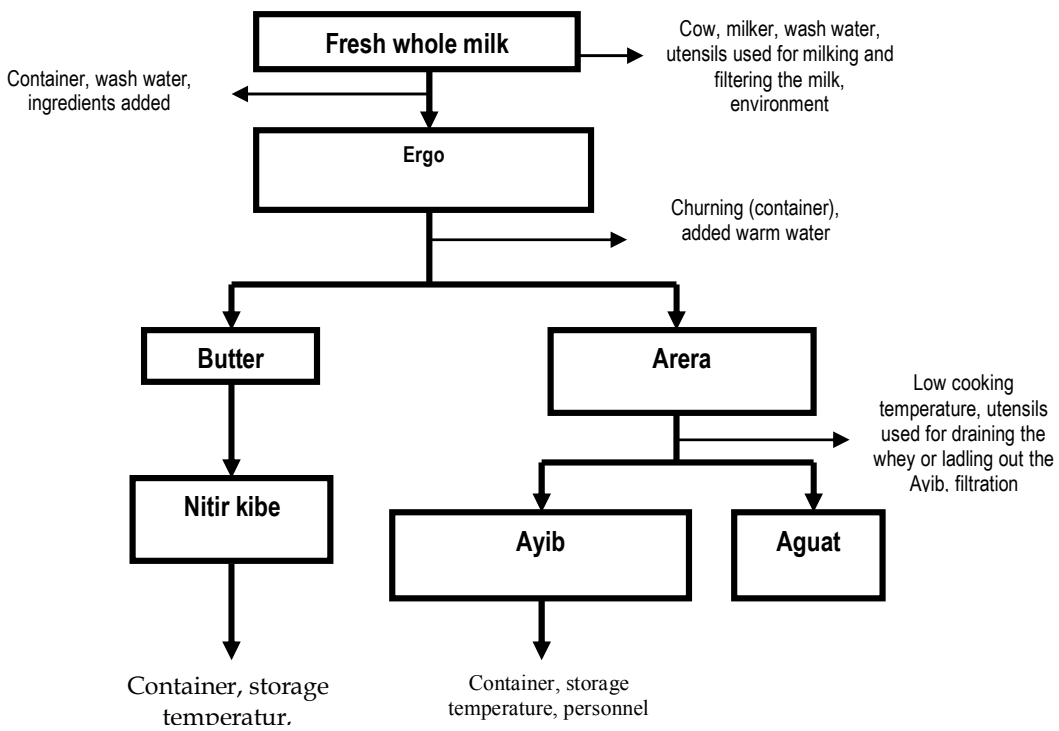

Fig. 7. Flow scheme of critical points of microbial contamination during traditional milk processing in the central Ethiopian highlands

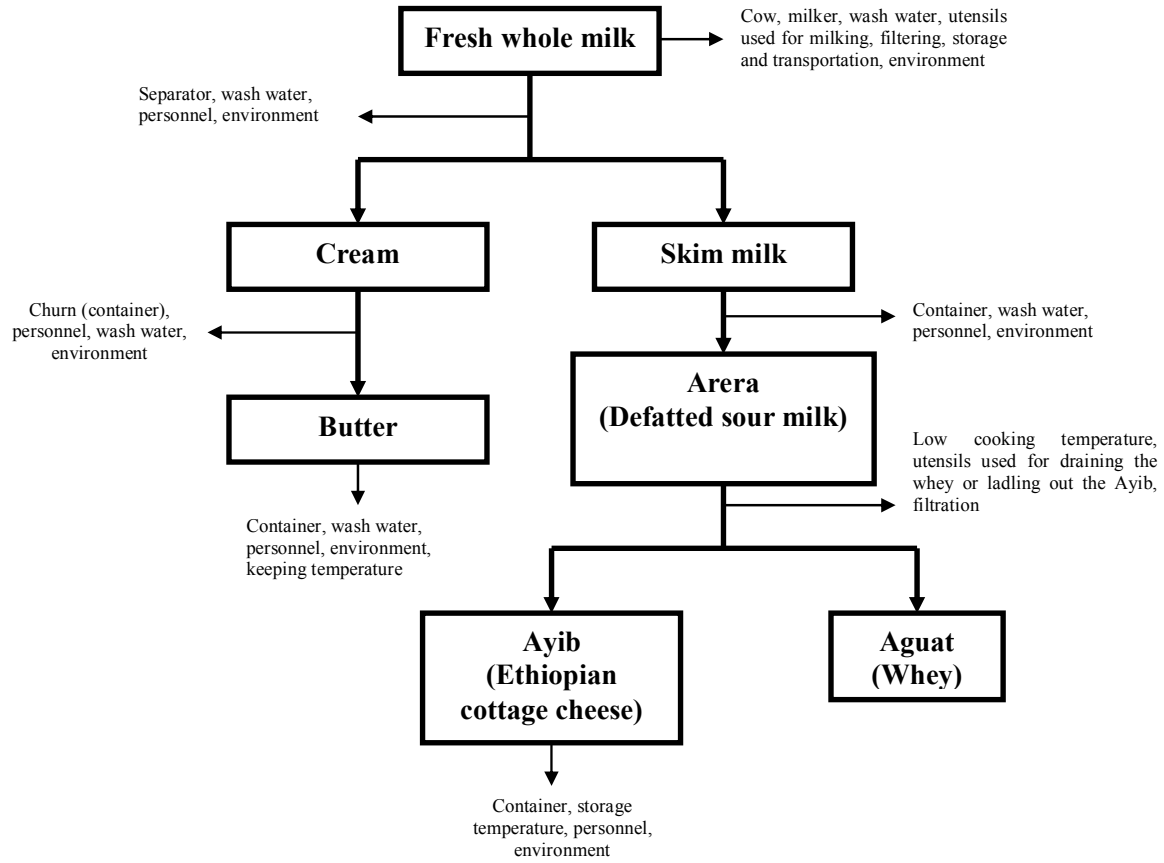

Fig. 8. Flow scheme of critical points of microbial contamination of milk and milk products at cooperative centers in different parts of Ethiopia 


\section{International quality standards practiced in different countries}

As food safety and quality are a growing concern all over the world, different organizations in many countries implement quality control programs and established quality standards for all food items including animal products to ensure the health of the consumer. Health hazards to the consumer are often grouped into microbiological, physical and chemical (FDA, 2004). A microbial criteria stipulate that a type of microorganism, groups of microorganisms, toxin produced by a microorganism must either not be present at all, be present in only a limited number of samples, or be present at less than a specified number or amount in a given quantity of a food ingredient (NRC, 1985).

Different microbiological tests are used to indicate the hygienic condition of manufacturing of a given product. Coliform count provides an indication of unsanitary production practices and/or mastitis infection. A count less than 100 Colony Forming Units (CFU)/ $\mathrm{ml}$ is considered acceptable for milk intended to be pasteurized before consumption. Counts of $10 \mathrm{CFU} / \mathrm{ml}$ or less are achievable and desirable if raw milk will be consumed directly (Jones and Sumner, 1999; Ruegg, 2003). Estimation of the total bacteria count is the procedure used to measure the general sanitary quality of milk. The number of bacteria in aseptically drawn milk varies from animal to animal and even from different quarters of the same animal. On average, aseptically drawn milk from healthy udders contains between 500 and 1000 bacteria ml- ${ }^{-1}$. High initial counts (>105 bacteria $\mathrm{ml}^{-1}$ ) are evidence of poor production hygiene (O'Connor, 1994). Somatic cell count (SCC) is another indirect indicator of the microbial quality of milk. The number of somatic cells increases in response to pus-producing bacteria like Staphylococcus aureus, a cause of mastitis (Kleinschmit and Gompert, 2007).

Legal and voluntary bacteriological standards vary widely from country to country and there are different standards for different groups and species of microorganisms specific to specific products. Standard plate count (SPC) values for raw milk can range from $<1000 \mathrm{ml}^{-1}$, where contamination during production is minimal, to $>1 \times 10^{5} \mathrm{ml}^{-1}$. Consequently, high initial SPC values $\left(>10^{5} \mathrm{ml}-1\right)$ are evidence of serious hygienic problem during production, likewise SPC values of $<2 \times 10^{4} \mathrm{ml}^{-1}$ reflect good sanitary practices (IDF, 1994).

\begin{tabular}{cccc}
\hline Somatic Cell Count/ml & Drug residue & Country & Source \\
\hline$<7.5 \times 10^{5}$ & Absent & USA & IFCN, 2006; CDFA, 2008 \\
$<4.99 \times 10^{5}$ & Absent & Canada & IFCN, 2006; CDFA, 2008 \\
$<4 \times 10^{5}$ & Absent & France & IFCN, 2006; CDFA, 2008 \\
$<4 \times 10^{5}$ & Absent & Sweden & IFCN, 2006; CDFA, 2008 \\
$<10^{6}$ & Absent & Russian & IFCN, 2006 \\
$<6 \times 10^{5}$ & Absent & Israel & IFCN, 2006 \\
$<4 \times 10^{5}$ & Absent & South Africa & IFCN, 2006 \\
$<7 \times 10^{5}$ & Absent & Brazil & IFCN, 2006 \\
$<5 \times 10^{5}$ & Absent & China & IFCN, 2006 \\
$<2.5 \times 10^{5}$ & Absent & Australia & IFCN, 2006 \\
\hline
\end{tabular}

Table 6. Commonly used safety limits of somatic cell count and drug residue for raw milk employed in selected countries

In many countries, a standard for Grade ' $\mathrm{A}$ ' raw milk is an SPC of $<10 \mathrm{ml}^{-1}$ for milk intended for heat treatment before consumption or further processing. For milk that is to be 


\begin{tabular}{|c|c|c|}
\hline Milk product & Microorganism & Maximum limit (cfu/ml or $\mathrm{g}$ ) \\
\hline \multirow{2}{*}{$\begin{array}{l}\text { Raw cow's milk intended } \\
\text { for processing }\end{array}$} & Total bacteria & $10^{5}$ \\
\hline & Staphylococcus aureus & $2 \times 10^{3}$ \\
\hline \multirow{3}{*}{$\begin{array}{l}\text { Raw cow's milk intended } \\
\text { for direct human consumption }\end{array}$} & Salmonella & Absent in $25 \mathrm{~g}$ \\
\hline & S. aureus & $5 \times 10^{2}$ \\
\hline & Total bacteria & $5 \times 10^{4}$ \\
\hline \multirow[t]{3}{*}{ Pasteurized drinking milk } & Pathogenic microorganisms & Absent in $25 \mathrm{~g}$ \\
\hline & Coliforms & 5 \\
\hline & Total bacteria & $5 \times 10^{5}$ \\
\hline UHT milk and sterilized milk & Total bacteria & 100 \\
\hline \multirow[t]{4}{*}{$\begin{array}{l}\text { Cheese made from raw and } \\
\text { thermized milk }\end{array}$} & Listeria monocytogenes & $\begin{array}{c}\text { Absent in } 1 \mathrm{~g} \text { hard cheese or in } \\
25 \mathrm{~g} \text { other cheese varieties }\end{array}$ \\
\hline & Salmonella & Absent in $1 \mathrm{~g}$ \\
\hline & S. aureus & $10^{4}$ \\
\hline & E. coli & $10^{5}$ \\
\hline \multirow{5}{*}{$\begin{array}{l}\text { Soft cheese made from } \\
\text { heat treated milk }\end{array}$} & L. monocytogenes & Absent in $25 \mathrm{~g}$ \\
\hline & Salmonella & Absent in $1 \mathrm{~g}$ \\
\hline & S. aureus & $10^{3}$ \\
\hline & E. coli & $10^{3}$ \\
\hline & Coliforms & $10^{5}$ \\
\hline \multirow[t]{3}{*}{ Fresh cheese } & L. monocytogenes & Absent in $25 \mathrm{~g}$ \\
\hline & Salmonella & Absent in $1 \mathrm{~g}$ \\
\hline & S. aureus & 100 \\
\hline \multirow[t]{3}{*}{ Butter } & L. monocytogenes & Absent in $25 \mathrm{~g}$ \\
\hline & Salmonella & Absent in $1 \mathrm{~g}$ \\
\hline & Coliforms & 10 \\
\hline \multirow{4}{*}{$\begin{array}{l}\text { Powdered milk and } \\
\text { milk based products }\end{array}$} & L. monocytogenes & Absent in $1 \mathrm{~g}$ \\
\hline & Salmonella & Absent in $1 \mathrm{~g}$ \\
\hline & S. aureus & 100 \\
\hline & Coliforms & 10 \\
\hline \multirow[t]{5}{*}{ Frozen milk based products } & L. monocytogenes & Absent in $1 g$ \\
\hline & Salmonella & Absent in $1 \mathrm{~g}$ \\
\hline & S. aureus & 100 \\
\hline & Coliforms & 100 \\
\hline & Total bacteria & $10^{5}$ \\
\hline \multirow[t]{3}{*}{ Liquid milk based products } & L. monocytogenes & Absent in $1 \mathrm{~g}$ \\
\hline & Salmonella & Absent in $1 \mathrm{~g}$ \\
\hline & Coliforms & 5 \\
\hline
\end{tabular}

Source: Council Directives 92/46 EEC (1992)

Table 7. Microbiological safety limits for selected milk products in community legislation in force by the European Commission

consumed raw, a more stringent standard is generally required because consumers of raw milk are at a greater risk for contracting a milk-borne illness such as salmonellosis. In some countries, standards adopted may depend on whether milk is refrigerated or merely water-cooled. For example, in North America, SPC values of $<10^{6} \mathrm{ml}^{-1}$ or equivalent are 
acceptable for manufacturing grade ' $\mathrm{A}$ ' milk. In contrast, in the UK no distinction is made between raw milk marketed for further processing and that marketed for fluid consumption (Chambers, 2002). Although on-farm testing and independent laboratory testing do not guarantee food safety, they are generally accepted means to monitor milk quality. In dairy developed countries, buying raw milk from a Grade ' $\mathrm{A}$ ' herd assures that the milk is tested for pathogens on a regular basis therefore is fit for further processing and consumption (Walstra et al., 2006). Quality related safety limits practiced in selected countries are presented in Table 6, while Table 7 depicts microbiological safety limits for selected milk products in community legislation in force by the European Commission.

\section{Conclusion}

The microbiological properties of marketed milk and milk products in different parts of Ethiopia are generally below standards. This is mainly due to unhygienic conditions at one or more of the stages in the dairy value chain from farm to table, which in turn might be attributed to inadequate dairy infrastructure coupled with limited knowledge on the hygienic production and handling of milk and milk products. Based on experiences from a number of countries, it is likely that problems with effective translation of knowledge to practice, rather than incomplete knowledge per se, are the more important constraints to national progress towards improved milk quality.

Currently, the Ethiopian dairy sector is developing and the involvement of the private sector is at the increase. Moreover, consumers are increasingly concerned about the quality of products and the production conditions. A concerted effort towards improving the qualities of milk and milk products and contributing to the betterment of the Ethiopian formal milk business is essential. This benefits both the producer through allowing entering into the competitive market and bringing increased income from the sale of quality products, and the consumer through creating access to products of acceptable quality.

From experiences of a number of countries, putting functional quality standards, quality control system and payment system based on quality in place resulted not only in improved quality of marketed milk but also the volume of milk delivered to collection centers and dairies. It is important that quality standards for milk and major milk products for Ethiopia, should take into consideration factors such as the prevailing conditions of facilities and infrastructures required for dairy development; the existing quality standards currently in use in different countries; and the actual qualities of milk and milk products being marketed in different parts of Ethiopia. Such an approach will improve the Ethiopian formal milk business.

\section{References}

Asfaw, M. M. (2008). Assessment of processing techniques and quality attributes of butter produced in Delebo water shade of Wolayita zone, Southern Ethiopia. Hawassa University. M.Sc. thesis.

Ashenafi M. (2002). The microbiology of Ethiopian foods and beverages: A review. SENET: Ethiopian Journal of Science. 25 (1):97-140. 
Ashenafi, M. (1990). Microbiological quality of Ayib, a traditional Ethiopian cottage cheese. International Journal of Food Microbiology, 10:261-268.

Ashenafi, M. (2006). A review on the microbiology of indigenous fermented food and beverages of Ethiopia. Ethiopian Journal of Biological Sciences 5(2), 189245.

Ashenafi, M. (1994). Fate of Listeria monocytogenes during the fermentation of Ergo, a traditional Ethiopian sour milk. Journal of Dairy Science 77, 696-702.

Assefa, E., Beyene, F. and Santhanam, A. (2008). Isolation and characterization of inhibitory substance producing lactic acid bacteria from Ergo, Ethiopian traditional fermented milk.

Beyene F. (1994). Present situation and future aspects of milk production, milk handling and processing of dairy products in Southern Ethiopia. Ph.D. Thesis. Department of Food Science, Agricultural University of Norway. Ås, Norway.

Bintsis, T., Angelidis A. S. and Psoni, L. (2008). Modern Laboratory Practices: Analysis of Dairy Products. In: Advanced dairy science and technology. Britz, T. J. and Robinson R. K. (Eds.). Blackwell Publishing Ltd, UK.

CDFA. (2008). New Coliform Standard for Milk Sold Raw to Consumers. California Department of Food and Agriculture (CDFA), Press Release on Raw Milk.

Chambers, J.V. (2002). The Microbiology of Raw Milk. Dairy Microbiology Handbook. Third Edition. Edited by Richard K. Robinson. John Wiley and Sons, Inc., New York.

Cody, S.H., Abbott, S.L., Marfin, A.A., Schulz, B., Wagner, P., Robbins, K., Mohle-Boetani, J.C., and Vugia, D.J. 1999. Two outbreaks of multidrug-resistant Salmonella serotype Typhimurium DT104 infections linked to raw-milk cheese in Northern California. JAMA. 281(19):1805-10. (Abs. PubMed).

Council Directives 92/46 EEC. (1992). Laying down the health rules for the production and placing on the market of raw milk, heat-treated milk and milk-based products. Official Journal of the European Communities, No L 268/1.

CSA. (2010). Agricultural Sample Survey. Livestock, Poultry and Beehives population (private peasant holdings). Federal Democratic Republic of Ethiopia Central Statistical Authority (CSA), Addis Ababa, Ethiopia.

Desenclos, J.C., Bouvet, F., Benz-Leloine, E., Grimont, F., Desqueyroux, H., Rebiere, I., and Grimont, P.A. (1996). Large outbreak of Salmonella enterica serotype Paratyphi B infection caused by a goats' milk cheese, France, 1993: a case finding and epidemiological study. BM, 312:91-94.

Duffy, G., Garvey, P. and Sheridan, J.J. (2002F). A European Study on Animal Food \& Biomedical Aspects of E. coli 0157:H7. The National Food Centre, Dunsinea, Castleknock, Dublin, Irland.

ENA. (2004). Milk, Dairy Products Loss Of Five African, Middle East Countries Stands At 90 Mln. USD, Ethiopian News Agency (ENA), Addis Ababa, 10/22/2004.

FAO. (1990). The technology of traditional milk products in developing countries. FAO Animal Production and Health Paper 85. Food and Agriculture Organization of the United Nations, Rome, Italy. 333 pp. 
FAO. (2010). Status and prospects for smallholder milk production - A global perspective, by T. Hemme and J. Otte. Rome.

Felleke G. (2003). Milk and Dairy Products, Post-harvest Losses and Food Safety in Sub-Saharan Africa and the Near East. A Review of the Small Scale Dairy Sector - Ethiopia. FAO Prevention of Food Losses Programme. FAO, Rome, Italy.

Francesconi G.N. (2006). Promoting milk quality of cooperative smallholders: Evidence from Ethiopia and implications for policy. In proc. of the 14th Annual conference of the Ethiopian Society of Animal Production (ESAP), Part II: Technical papers, held on September 5 - 7, 2006, Addis Ababa, Ethiopia. pp 31-41.

Gadaga, T.H., Mutukumira, A.N. and Narvhus, J.A. (2000). Enumeration and identification of yeasts isolated from Zimbabwean traditional fermented milk. International Dairy Journal 10; 459-466.

Giangiacomo, R. (2000). Milk testing, quality control, hygiene and safely. FAO e-mail conference on "Small-scale milk collection and processing in developing countries". June 6 - August 3, 2000. 108 p.

Godefay, B. and B. Molla. (2000). Bacteriological quality of raw cow's milk from four dairy farms and a milk collection center in and around Addis Ababa. Berl. Munch. Tierarztl. Wochenschr. 113:276-278.

Gonfa, A., Foster, H.A., Holzapfel, W.H. (2001). Field survey and literature review on traditional fermented milk products of Ethiopia. Int. J. Food Microbiol. 68, 173186.

Ibrahim, H. and Olaluku, E. (2000). Improving cattle for milk, meat and traction. ILRI Manual 4. International Livestock Research Institute (ILRI), Nairobi, Kenya, pp. 135.

IDF. (1994). Recommendations for the hygienic manufacture of milk and milk based products. Bulletin of the International Dairy Federation (IDF). No. 292, 32 p.

IFCN. (2006). Dairy Report 2006. For a better understanding of milk production world-wide. International Farm Comparison Network (IFCN) Dairy Research Center, Kiel, Germany.

ILCA. (1992). Alternative milk processing and preservation techniques and the quality of market butter and cheese. Annual program report 1991. International Livestock Centre for Africa. Addis Ababa, Ethiopia. pp. 39-40.

Jones G.M. and Sumner S. (1999). Testing bulk milk samples. Dairy. Publication 404-405. Virginia Cooperative Extension. Virginia State University.

Kassa, B. E. (2008). Cottage cheese production in Shashemane and the role of Rue (Ruta chalepensis) and garlic (Allium sativum) on its quality and shelf life. Hawassa University. M.Sc. Thesis.

Kleinschmit, M., and Gompert, T. (2007). Raw Milk Use and Safety Fact Sheet. Center for Rural Affairs, Northeast Nebraska RC\&D, Plainview, Nebraska.

Le Marc, Y., Valík, L. and Medved'ová, A. (2009). Modelling the effect of the starter culture on the growth of Staphylococcus aureus in milk. International Journal of Food Microbiology 129: 306-311. 
Mahari, T. and B.A. Gashe. (1990). A survey of the microflora of raw and pasteurized milk and the sources of contamination in a milk processin plant in Addis Ababa, J Dairy Res, 57(2):233-8.

Mamo, W. K. (2007). Composition, microbial quality and acceptability of butter produced from the milk of dairy cows in Hawassa, Southern Ethiopia. Hawassa university. M.Sc. thesis. Pp 89.

Mostert, J.F. and Jooste, P.J. (2002). Quality Control in The Dairy Industry. Dairy Microbiology Handbook. Third Edition. Edited by Richard K. Robinson. John Wiley and Sons, Inc., New York. P 655- 736.

Nebiyu, R.G. (2008). Traditional and improved milk and milk products handling practices and compositional and microbial quality of raw milk and buttermilk in Delebo water shade of Wolayita zone, Ethiopia. Hawassa University. M.Sc. thesis.

NRC. (1985). An evaluation on microbiological criteria for foods and food ingredients. Subcommittee on microbiological criteria, Committee on Food Protection, National Research Council (NRC).

O'Connor, C.B. (1993). Traditional cheese making manual. ILCA (International Livestock centre for Africa), Addis Ababa, Ethiopia. 43 pp.

O'Connor, C.B. (1994). Rural dairy technology. ILRI training manual 1. ILRI (International Livestock Research Institute), Addis Ababa, Ethiopia. pp. 133.

O'Connor, C.B. (1992). Rural smallholder milk production and utilization and the future for dairy development in Ethiopia. Dairy marketing in Sub-Saharan Africa. Proceeding of a symposium held at ILCA, Addis Ababa, Ethiopia. 26-30 November 1990. International Livestock Center for Africa, Addis Ababa, Ethiopia. pp. 123-130.

O'Mahony, F. and Peters, J. (1987). Sub-Saharan Africa. Options for smallholder milk processing. Food and Agriculture Organisation of the United Nations. World Animal Review. No. 62. pp.16-30.

Reda, T. (1998). Milk processing and marketing options for rural small-scale producers. In: National Conference of the Ethiopian Society of Animal Production (ESAP), pp. 6167.

Ruegg P.L. (2003). Practical food safety interventions for Dairy Production. J. Dairy Sci. 86: (E. Suppl.):E1-E9.

Spreer, E. (1998). Milk and dairy product technology. Mixa, A (translator). Marcel Dekker, INC. ISBN: 0-8247-0094-5. New York, pp. 39-58.

Tola A. (2002). Traditional milk and milk products handling practices and raw milk quality in Eeastern Wollega. MSc thesis. Alemaya University, Alemaya, Ethiopia. 108 pp.

Walstra, P., Wouters. Jan T.M. and Geurts, T.J. (2006). Dairy Science and Technology Second Edition. CRC Press Taylor \& Francis Group. P 763.

Yilma, Z. (1999). Smallholder Milk Production Systems and Processing Techniques in the central high lands of Ethiopia. MSc Thesis, Swedish University of Agricultural Sciences Uppsala, Sweden 132p.

Yilma, Z. (2003). Sanitary conditions and microbial qualities of dairy products in urban and peri-urban dairy shed of the central Ethiopia. DEA. Lyon, France.

Yilma, Z., Faye, B and Loiseau, G. (2005). Microbial properties of butter and Ethiopian cottage cheese (Ayib). Ethiop. Vet. J., 2005, 9 (1), 43-57. 
Yilma, Z., Faye, B and Loiseau, G. (2007). Occurrence and distribution of species of Enterobacteriaceae in selected Ethiopian traditional dairy products: A contribution to epidemiology. Food Control 18 (2007) 1397-1404.

Yilma. Z. and Faye, B. (2006). Handling and Microbial Load of Cow's Milk and Irgo Fermented Milk Collected from Different Shops and Producers in Central Highlands of Ethiopia. Eth. J. Anim. Prod. 6(2): 67-82. 


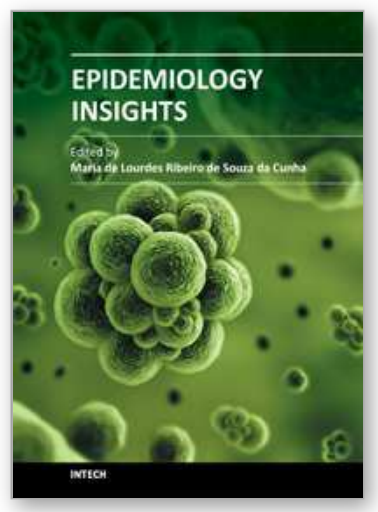

\author{
Epidemiology Insights \\ Edited by Dr. Maria De Lourdes Ribeiro De Souza Da Cunha
}

ISBN 978-953-51-0565-7

Hard cover, 396 pages

Publisher InTech

Published online 20, April, 2012

Published in print edition April, 2012

This book represents an overview on the diverse threads of epidemiological research, brings together the expertise and enthusiasm of an international panel of leading researchers to provide a state-of-the art overview of the field. Topics include the epidemiology of dermatomycoses and Candida spp. infections, the epidemiology molecular of methicillin-resistant Staphylococcus aureus (MRSA) isolated from humans and animals, the epidemiology of varied manifestations neuro-psychiatric, virology and epidemiology, epidemiology of wildlife tuberculosis, epidemiologic approaches to the study of microbial quality of milk and milk products, Cox proportional hazards model, epidemiology of lymphoid malignancy, epidemiology of primary immunodeficiency diseases and genetic epidemiology family-based. Written by experts from around the globe, this book is reading for clinicians, researchers and students, who intend to address these issues.

\title{
How to reference
}

In order to correctly reference this scholarly work, feel free to copy and paste the following:

Zelalem Yilma (2012). Microbial Properties of Ethiopian Marketed Milk and Milk Products and Associated Critical Points of Contamination: An Epidemiological Perspective, Epidemiology Insights, Dr. Maria De Lourdes Ribeiro De Souza Da Cunha (Ed.), ISBN: 978-953-51-0565-7, InTech, Available from: http://www.intechopen.com/books/epidemiology-insights/microbial-properties-of-marketed-milk-and-ethiopianfermented-milk-products-and-associated-critical

\section{INTECH}

open science | open minds

\section{InTech Europe}

University Campus STeP Ri

Slavka Krautzeka 83/A

51000 Rijeka, Croatia

Phone: +385 (51) 770447

Fax: +385 (51) 686166

www.intechopen.com

\section{InTech China}

Unit 405, Office Block, Hotel Equatorial Shanghai

No.65, Yan An Road (West), Shanghai, 200040, China

中国上海市延安西路65号上海国际贵都大饭店办公楼 405 单元

Phone: +86-21-62489820

Fax: $+86-21-62489821$ 
(C) 2012 The Author(s). Licensee IntechOpen. This is an open access article distributed under the terms of the Creative Commons Attribution 3.0 License, which permits unrestricted use, distribution, and reproduction in any medium, provided the original work is properly cited. 